\title{
PROFESIONALISME GURU PENDIDIKAN KHUSUS DI DAERAH ISTIMEWA YOGYAKARTA
}

\author{
Ida Ayu Dian Pramantik, Pardjono \\ SLB Negeri I Bantul Yogyakarta, Universitas Negeri Yogyakarta \\ idayudianp@gmail.com, jpardjono@yahoo.com
}

\begin{abstract}
Abstrak
Penelitian ini bertujuan menggambarkan profesionalisme guru pendidikan khusus di Daerah Istimewa Yogyakarta. Hasil penelitian profesionalisme guru pendidikan khusus berkaitan dengan profesionalisme guru pendidikan khusus. Profesionalisme guru pendidikan khusus ditinjau berdasarkan empat kompetensi guru, yaitu: (1) kompetensi pedagogik, untuk seluruh responden membuat perencanaan pembelajaran. Responden SMR memahami kondisi siswa dan memandirikan siswa, sedangkan responden BP berupaya memandirikan siswa; (2) kompetensi kepribadian, untuk seluruh responden menunjukkan sikap sebagai panutan, disiplin, bekerja dengan ikhlas. Tiga responden selain responden BP, memberikan pengabdian yang tulus, tanggung jawab terhadap pekerjaan, berpikir positif, dan menjaga kepercayaan; (3) kompetensi sosial, untuk responden HT dan SMR mewujudkan dengan sikap tidak diskriminatif, sedangkan responden BP dan BSN mewujudkannya dengan lebih berperan aktif dalam kegiatan di masyarakat; (4) kompetensi profesional, untuk seluruh responden menunjukkan dengan belajar terus menerus, mengikuti workshop dan diklat, serta menulis buku dalam bidang pengembangan pembelajaran. Responden SMR juga menunjukkan dengan mengikuti lomba, sedangkan responden $\mathrm{BP}$ dengan menempuh jenjang pendidikan yang lebih tinggi dan mengikuti kegiatan organisasi kependidikan. Bentuk pengembangan profesionalisme yang dilakukan oleh seluruh responden tampak jelas dalam kompetensi profesional, yaitu melalui kegiatan workshop, diklat, lomba, berorganisasi, maupun pengembangan yang dilakukan secara pribadi seperti menulis, dan menempuh pendidikan lanjut.
\end{abstract}

Kata kunci: profesionalisme guru, guru pendidikan khusus

\section{PROFESIONALISM OF SPECIAL EDUCATION TEACHERS IN YOGYAKARTA SPECIAL TERRITORY}

Ida Ayu Dian Pramantik, Pardjono

SLB Negeri I Bantul Yogyakarta, Universitas Negeri Yogyakarta idayudianp@gmail.com,jpardjono@yahoo.com

\begin{abstract}
This study aims to discover Professionalism of Special Education Teachers in Special Region of Yogyakarta. Professionalism of special education teachers could be regarded based on four teacher competencies: (1) pedagogic competency, all respondent made lesson plan. Respondent SMR understood students conditions and strove for them to be independent, while respondent BP strove for students independence; (2) personality competency, all respondent have become example of discipline and work ethics. Three respondent, except BP, have demonstrated dedication, responsibility, positive thinking, and trustworthiness; (3) social competency, respondent HT and SMR have embodied attitude without discrimination, while respondent BP and BSN showed this competency by actively involved in society activities; (4) professional competency, all respondent continue learning, involve in workshops and trainings, and write instructional development books. Respondent SMR also contributes in several competetions, while respondent BP has taken higher education and involved in several educational organizations activities. Based on the research, there are several forms of professional development for special education teachers, as stated before, such as involving in workshops and training, competitions, organizations, and keeping on personal development, for example writing and taking higher education.
\end{abstract}

Keywords: teacher professionalism, special education teacher 



\section{Pendahuluan}

Peranan guru semakin penting dalam era global. Hanya melalui bimbingan guru yang profesional, setiap siswa dapat menjadi sumber daya yang berkualitas, kompetitif dan produktif sebagai aset nasional dalam mengahadapi persaingan yang semakin ketat dan berat diera sekarang dan dimasa yang aan datang. Banyak peranan yang diperlukan dari guru sebagai seorang pendidik. Djamarah (2005, pp. 43-48) mengungkapkan bahwa: Peranan menjadi guru adalah sebagai berikut: sebagai korektor; sebagai inspirator; sebagai informator; sebagai organisator; sebagai motivator; sebagai inisiator; sebagai fasiliator; sebagai pembimbing; sebagai demonstrator; sebagai pengelola kelas; sebagai mediator; sebagai supervisor; dan sebagai evaluator.

Hal tersebut dapat dijelaskan bahwa guru memiliki peranan yang sangat banyak. Guru tidak hanya memberikan informasi kepada peserta didik atau membimbing saja tetapi harus mampu memberikan inspirasi bagi peserta didiknya, memberikan dorongan serta memfasilitasi peserta didiknya dalam kegiatan pembelajaran sampai dengan mengevaluasi kegiatan-kegiatan pembelajaran yang dilakukan oleh peserta didiknya. Sehingga guru dituntut untuk dapat bekerja secara profesional dalam kegiatan pembelajaran.

Profesionalisme merupakan sikap profesional yang mengajarkan bahwa setiap pekerjaan harus dilakukan oleh orang yang profesional. Seseorang dapat dikatakan profesional apabila memiliki keahlian dalam melakukan pekerjaannya. Seorang profesional memberikan layanan pekerjaan sesuai dengan kompetensi yang dimilikinya. Dengan demikian seorang guru harus mampu melakukan tugasnya secara profesional.

Selain itu profesionalisme juga harus ditempuh dengan mengikuti pendidikan profesi sesuai dengan bidang pekerjannya. Namun pada kenyataanya masih ada guru pendidikan khusus di Daerah Istimewa Yogyakarta yang belum menempuh pendidikan profesi guru. Dengan adanya fenomena tersebut maka pemerintah segera melakukan pendidikan profesi guru bagi guru-guru yang belum memiliki sertifikat pendidik yang merupakan tolok ukur bagi guru profesional.

Meskipun kinerja guru profesional itu sudah jelas, tetapi kenyataanya masih ada guru pendidikan khusus yang telah memiliki sertifikat pendidik sebagai acuan guru profesional itu yang belum menunjukkan sikap keprofesionalannya dengan guru yang datang sekolah terlambat, yang dilakukannya hampir setiap hari. Hal tersebut menunjukkan bahwa secara kepribadian guru yang datang terlambat tidak mampu membagi waktu dengan sebaikbaiknya sebagai bentuk kedisiplinan yang merupakan wujud dari kompetensi kepribadian. Sedangkan guru merupakan bagian terpenting dalam proses kegiatan belajar mengajar karena guru sebagai ujung tombak yang berhadapan langsung dengan siswa dalam proses pembelajaran. Guru juga berperan sebagai teladan dalam belajar, berperilaku, dan berpikir untuk masa depan. Selain itu, guru juga dapat menjadi teman diskusi dan mencurahkan gagasan serta pengetahuan peserta didiknya.

Profesionalisme guru diakui pemerintah dengan adanya program sertifikasi. Hal ini telah dijelaskan dalam UndangUndang Nomor 14 Tahun 2005 Tentang Guru dan Dosen Pasal 1 Ayat 12 yang menyatakan bahwa "sertifikat pendidik adalah bukti formal sebagai pengakuan yang diberikan kepada guru dan dosen sebagai tenaga profesional". Dapat dijelaskan bahwa sertifikasi guru adalah pengakuan formal dari pemerintah terhadap sosok guru sebagai tenaga profesional. Sertifikasi juga dibutuhkan untuk mempertegas standar kompetensi yang harus dimiliki oleh para guru sesuai dengan bidang keilmuannya masing-masing.

Sertifikasi guru merupakan pemenuhan kebutuhan untuk meningkatkan kompetensi profesional. Sertifikasi guru merupakan proses uji kompetensi bagi calon guru atau guru yang ingin memperoleh pengakuan dan atau meningkatkan kompetensi sesuai profesi yang dipilihnya. Oleh karena itu, "proses sertifikasi dipan- 
dang sebagai bagian esensial dalam upaya memperoleh sertifikat kompetensi sesuai dengan standar yang telah ditetapkan" (Borang, 2010, p. 247).

Profesionalisme guru perlu dijabarkan karena fakta di lapangan banyak guru yang telah memiliki sertifikat pendidik tetapi tidak menggambarkan guru yang profesional sesuai dengan kemampuan dan kompetensi yang dimilikinya. Dengan kata lain guru yang telah memiliki sertifikat pendidik tidak menjadi jaminan guru tersebut profesional. Hardianto $(2009$, p. 7) mengatakan bahwa "sertifikat guru profesi yang disandang belumlah jaminan bahwa seseorang guru sudah profesional". Hal tersebut juga dijelaskan Hal ini jelas melenceng dari tujuan dan manfaat diberikannya sertifikasi. Padahal pemerintah telah mengeluarkan dana yang sangat besar untuk mengadakan program sertifikasi.

Guru profesional adalah guru yang mampu menerapkan hubungan yang berbentuk multidimensional. Guru yang demikian adalah guru yang mempunyai tanggung jawab sosial, intelektual, moral, dan spiritual" (Mudlofir, 2012, p.110). Tanggung jawab pribadi yang mandiri mampu memahami dirinya, mengelola dirinya, mengendalikan dirinya, menghargai serta mengembangkan dirinya. Tanggung jawab sosial diwujudkan melalui kompetensi guru dalam memahami dirinya sebagai bagian yang tak terpisahkan dari lingkungan sosial serta memiliki kemampuan interaksi yang efektif. Tanggung jawab intelektual diwujudkan melalui penguasaan berbagai perangkat pengetahuan dan keterampilan yang diperlukan untuk menunjang tugas-tugasnya. Tanggung jawab spiritual dan moral diwujudkan melalui penampilan guru sebagai makhluk yang beragama yang perilakunya senantiasa tidak menyimpang dari norma-norma agama dan moral.

Pengertian lain mengenai guru profesional juga dikemukakan oleh Borang (2010, p. 246) bahwa guru profesional adalah guru yang mengajar pada mata pelajaran yang menjadi keahliannya, mempunyai semangat tinggi dalam mengembangannya dan menjadi pioneer perubahan di tengah masyarakat.

Guru profesional adalah guru yang mampu bekerja keras atas dasar motivasi diri, disiplin diri, evaluasi diri, kesadaran diri, pengembangan diri, berempati, dan mampu melakukan hubungan secara efektif, serta bekerja dipandu oleh kode etik profesinya (Danim, 2011, p. 12). Pendapat lainnya mengenai guru profesional (Hamalik, 2009, p. 27) merupakan orang yang telah menempuh program pendidikan guru dan memiliki tingkat master serta telah mendapat ijazah negara dan telah berpengalaman dalam mengajar pada kelas-kelas besar.

Penjelasan tersebut mengarahkan kita pada guru yang profesional itu adalah guru yang memiliki kompetensi yang di persyaratkan, memiliki kemampuan dan keahlian khusus dalam bidang keguruan, serta telah terdidik dan terlatih secara baik serta memiliki pengalaman yang kaya dibidangnya dan mampu melakukan pengembangan diri. Tulisan Hugh Sockett dalam Case, et al, (2009, p. 19) menggambarkan dasar moral profesionalisme dalam mengajar ada empat dimensi utama dalam profesionalisme guru, yaitu: (1) komunitas profesional, (2) keahlian profesional, (3) tanggung jawab profesional, dan (4) pelayanan terbaik profesi.

Pengembangan profesionalisme guru merupakan tugas bersama antara guru dengan institusi atau dinas pendidikan. Bentuk pengembangan profesionalisme guru ada dua jenis, yaitu: pengembangan karir dan pengembangan profesi. Pengembangan karir berkaitan dengan penugasan, kenaikan pangkat, dan promosi.Sedangkan pengembangan profesi berkaitan dengan pengembangan empat standar kompetensi guru yaitu kompetensi pedagogik, kompetensi kepribadian, kompetensi profesional, dan kompetensi sosial.

Danim (2011, p. 3) menjelaskan mengenai empat ranah (taxonomy) dalam mewujudkan guru yang benar-benar profesional. Keempat ranah tersebut antara lain penyediaan guru berbasis perguruan tinggi, induksi guru pemula berbasis sekolah, pro- 
fesionalisasi guru berbasis prakarsa institusi, profesionalisasi guru berbasis individu.

Berkaitan dengan penyediaan guru, Undang-Undang Nomor 14 Tahun 2007 tentang Guru dan Dosen dan Peraturan Pemerintah Nomor 74 Tahun 2008 tentang Guru telah menggariskan bahwa hal ini menjadi kewenangan lembaga pendidikan tenaga kependidikan. Lembaga pendidikan tenaga kependidikan yang dimaksud adalah perguruan tinggi yang diberi tugas oleh pemerintah untuk menyelenggarakan program pengadaan guru pada pendidikan anak usia dini jalur pendidikan formal, dasar, dan/atau menengah, serta untuk menyelenggarakan dan mengembangkan ilmu kependidikan dan non-kependidikan. Guru dimaksud harus memiliki kualifikasi akademik sekurang S-1/D-4 dan bersertifikat pendidik. Jika seorang guru telah memiliki keduanya, statusnya diakui oleh negara sebagai guru profesional.

Program induksi merupakan masa transisi bagi guru pemula (begining teacher) terhitung mulai dia pertama kali menginjakkan kaki di sekolah atau satuan pendidikan hingga benar-benar layak dilepas untuk mengerjakan tugas pendidikan dan pembelajaran secara mandiri. Yang dimaksud dengan guru pemula seperti yang tercantum dalam Permendiknas Nomor 27 Tahun 2010 Pasal 1 Ayat 2 menyebutkan bahwa guru pemula adalah guru yang baru pertama kali ditugaskan melaksanakan proses pembelajaran/bimbingan dan konseling pada satuan pendidikan yang diselenggarakan oleh Pemerintah, pemerintah daerah, atau masyarakat. Disampaikan oleh Hinds (2007, p. 7) bahwa "Beginning teachers needed subject content and instructional strategies consistent with their assignments, mentoring, and skills in mapping the curriculum; mid-career teachers needed training on inclusive classrooms, opportunities for collaborative work, and career counseling; and experienced teachers needed challenges for renewal, mentoring in communications technology and student assessment, and opportunities for promotions."
Kegiatan prakarsa dari lembaga ini menjadi sangat penting karena secara umum bagi guru-guru pemula masih memiliki keterbatasan baik secara finansial, jaringan, waktu, akses dan sebagainya. "Therefore, institutional assistance for teacher educators professional development would be most effective and powerful, although multiple contextual assistances are also required". (Hyeyoung Hwang, 2010, p. 1). Kegiatan pengembangan guru yang dilakukan atas inisiatif institusi pada umumnya berupa pendidikan dan pelatihan, workshop, magang, dan studi banding.

Kesempatan menjalani pengembangan profesionalisasi dapat dikatakan sangat sulit didapatkan oleh guru. Banyak guruguru yang selama menjalankan tugas dan fungsinya belum sempat menjalani proses pengembangan kecuali pada saat mereka menempuh pelatihan pra-jabatan dari Calon Pegawai Negeri Sipil (CPNS) menjadi Pegawai Negeri Sipil (PNS) penuh (Danim, 2011. p. 8). Menghadapi realita seperti ini, seorang guru harus melakukan profesionalisasinya secara mandiri agar tetap mampu menyesuaikan diri dengan kondisi saat ini maupun di masa mendatang.

Ahli lain mengenai bentuk pengembangan profesionalisme yaitu dari Eunjung Choi (2010, p. 5) "Professional development of teachers was done in two differentways: teacher preparation program, and in-service training. In-service training can becategorized in two types: (a) attending conferences or workshops outside of the setting, and (b) sharing knowledge and skills with other teachers in the setting, and this processoverlapped with the way teachers collaborate each other."

Pengembangan profesionalisme guru juga perlu dilakukan oleh guru yang menangani anak berkebutuhan khusus.Guru yang menangani anak berkebutuhan khusus tersebut kita kenal dengan guru pendidikan khusus. Hal tersebut tercantum dalam Permendiknas Nomor 32 Tahun 2008 Pasal 1 Ayat 2 bahwa "Guru pendidikan khusus adalah tenaga pendidik yang memenuhi kualifikasi akademik, kompetensi, dan sertifikasi pendidik bagi peserta didik 
yang memiliki kelainan fisik, emosional, mental, intelektual, sosial dan/atau potensi kecerdasan dan bakat istimewa pada satuan pendidikan khusus, satuan pendidikan umum, dan/atau satuan pendidikan kejuruan."

Profesionalisme guru pendidikan khusus menjadi sebuah pembahasanyang menarik karena guru pendidikan khusus memiliki kompetensi tertentu yang tidak dimiliki oleh guru pada sekolah umum. Kompetensi tersebut yaitu melakukan asesmen potensi dan hambatan peserta didik berkebutuhan khusus serta melakukan pengembangan program kekhususan braille, orientasi mobilitas, bina persepsi bunyi dan irama, bina diri, bina gerak, bina pribadi dan sosial, dan bina potensi kecerdasan dan bakat istimewa. Selain itu, untuk menjadi guru pendidikan khusus harus melewati uji kelayakan dan kesetaraan bagi guru dalam bidang-bidang tertentu.Seperti yang tercantum dalam Permendiknas Nomor 32 Tahun 2008 pada Bab III Penjelasan Tentang Standar Kualifikasi Akademik Guru Pendidikan Khusus bahwa Kualifikasi akademik yang dipersyaratkan untuk dapat diangkat sebagai guru dalam bidang-bidang tertentu yang sangat diperlukan pada satuan pendidikan khusus, tetapi belum dikembangkan di perguruan tinggi, dapat diperoleh melalui uji kelayakan dan kesetaraan. Uji kelayakan dan kesetaraan bagi seseorang yang memiliki keahlian tanpa ijazah dilakukan oleh perguruan tinggi yang diberi wewenang untuk melaksanakannya.

Hasil penelitian ini nantinya diharapkan dapat dapat digunakan sebagai salah satu informasi awal dalam pengembangan keilmuan terkait profesionalisme guru pendidikan khusus. Secara praktis, hasil penelitian ini dapat digunakan sebagai gambaran mengenai profesionalisme guru pendidikan khusus dan bentuk pengembangan profesionalismenya.

\section{Medote Penelitian}

Penelitian ini menggunakan pendekatan kualitatif dengan jenis penelitian fenomenologi. Tujuan dari penelitian ini adalah mendeskripsikan data yang sesuai dengan keadaan di lapangan tanpa adanya manipulasi data.

Penelitian penelitian kualitatif disebut juga sebagai penelitian naturalistik, disebut kualitatif karena sifat data yang dikumpulkan yang bercorak kualitatif, bukan kuantitatif, karena tidak menggunakan alat-alat pengukur. Disebut naturalistik, karena situasi lapangan bersifat natural atau wajar, sebagaimana adanya, tanpa dimanipulasi, diatur dengan eksperimen atau tes (Nasution, 1988, p. 18).

Penelitian ini dilakukan pada guru pendidikan khusus yang bekerja di Daerah Istimewa Yogyakarta yang dilaksanakan pada bulan Februari sampai dengan bulan Mei 2014. Subjek penelitian ini yaitu guru pendidikan khusus yang profesional yang bekerja di Daerah Istimewa Yogyakarta. Subjek yang diambil guna penelitian ini berjumlah sebanyak empat orang. Kriteria pemilihan subjek dalam penelitian ini adalah guru yang Guru pendidikan khusus di Daerah istimewa Yogyakarta yang telah memiliki sertifikat pendidik, memiliki mobilitas kerja yang tinggi, guru memiliki piagam penghargaan di tingkat nasional, memiliki karya yang dipakai untuk pengembangan Sekolah Khusus baik dalam bidang pembelajaran maupun di luar bidang pembelajaran.

Selain subjek juga ada informan. Informan ini adalah orang-orang yang dekat dan mengenal baik dengan subjek. Informan lain yang terlibat adalah guru yang sama-sama bekerja dengan subjek di sekolah dan mengenal subjek dalam keseharian dirumah.

Data-data dan informasi yang dikumpulkan dalam penelitian ini adalah informasi mengenai perjalanan karir guru, profesionalisme kinerga guru, serta bentuk pengembangan profesionalisme guru pendidikan khusus di Daerah Istimewa Yogyakarta. Teknik yang digunakan untuk mengumpulkan data dalam penelitian ini yaitu teknik wawancara dan dokumentasi.

Instrumen dalam penelitian ini yaitu peneliti. Pengumpulan data yang diguna- 
kan yakni pedoman wawancara dan dokumentasi yang telah disusun. Instrumen pendukung disusun secara semi permanen, artinya masih dapat dikembangkan lebih lanjut sesuai situasi yang ada.

Dalam penelitian ini keabsahan data dilakukan uji kredibilitas data atau kepercayaan terhadap data hasil penelitian kualitatif antara lain dilakukan dengan cara memperpanjang waktu pengambilan data, trianggulasi, dan member check

Alur analisis mengikuti model interaktif dengan metode induktif. Proses analisis data dalam penelitian ini dilaksanakan melalui empat tahapan yaitu: tahap pengumpulan data (data collection), tahap reduksi data (data reduction), tahap penyajian data (data display), tahappenarikan kesimpulan dan verifikasi. Pada penyajian data dilakukan pengkodean pada hasil wawancara untuk mempermudah pembaca dalam memahami data yang disajikan.

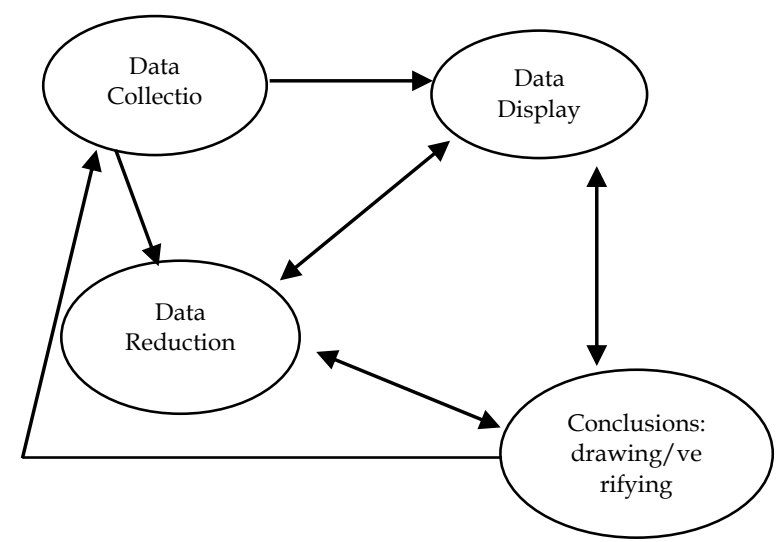

Milles $\mathcal{E}$ Huberman (1994, p. 12)

Gambar 1. Componen Analysis Data: Interactive Model

\section{Hasil Penelitian dan Pembahasan}

Profesionalisme guru pendidikan khusus yang didasarkan empat standar kompetensi guru yaitu kompetensi pedagogik, kompetensi kepribadian, kompetensi sosial, dan kompetensi profesional dijabarkan dibawah ini sesuai dengan yang telah dilakukan masing-masing subjek. Setiap subjek memiliki cara yang berbedabeda untuk mengembangkan profesionalisme sebagai seorang guru. Setiap kompetensi guru akan dijabarkan sebagai berikut:
Kompetensi Pedagogik

\section{Responden HT}

Kompetensi pedagogik seorang guru pendidikan khusus dapat terlihat salah satunya dengan mampu mengelola perilaku siswa. Hal ini ditegaskan oleh subjek HT pada W/HT/06-01-2014,yaitu: "kebutuhannya kan macem-macem, jadi misalnya dari bidang psikologi misalnya ya tepat-tepat saja karena disitu kan nanti bisa mengelola perilaku anak"

Dalam melaksanakan kompetensi pedagogik subjek HT yaitu merencanakan pembelajaran dari membuat perencanaan pembelajaran, evaluasi sampai dengan pelaksanaan tindak lanjut. Seperti yang disampaikan dalam wawancara subjek HT pada W/HT/06-01-2014, yaitu: "kita harus mempersiapkan diri seperti itu, kalau kita tidak mempersiapkan diri mengenai apa yang akan kita ajarkan pada anak esok tidak kta persiapkan berarti dia bukan guru yang profesional. Karena apapun harus ada persiapannya, kita kan harus ada perencanaan nantinya ada tindak anjut ada evaluasinya."

Dalam mengembangkan potensi secara pedagogiknya yang lain yaitu melaksanakan tugas-tugas pokok guru. Seperti pada hasil wawancara lainnya masih dengan subjek yang sama dalam wawancara yang sama W/HT/06-01-2014 pula dijelaskan: "melaksanakan tugas-tugas pokok guru"

Cara lainnya mengembangkan kompetensi pedagogik yaitu memandirikan siswa. Penjelasan tersebut dipertegas oleh subjek HT pada W/HT/06-01-2014 bahwa "tanggungjawab kita tidak hanya anak harus pandai tetapi bagaimana anak harus mandiri, mandiri kan juga bermacam-macam, bagaimana anak kita mandiri bisa mandi sendiri, bisa pakai baju sendiri, punya keterampilan"

Penjelasan tersebut juga menjelaskan adanya rasa tanggungjawab yang harus dijunjung tinggi oleh guru pendidikan khusus yang menjadi salah satu nilai dalam kompetensi kepribadian. Selain itu guru juga harus mampu memahami kondisi sis- 
wa baik kelebihan maupun kekurangannya. Hal tersebut masih juga dijelaskan oleh subjek HT pada W/HT/06-01-2014: "kita harus selalu melihat kondisi siswa, kelemahan siswa"

\section{Responden SMR}

Kemampuan pedagogik yang dikembangkan oleh subjek SMR yaitu memandirikan siswa dengan mengembangkan kemampuan siswa disektor apapun yang mampu untuk dikuasai siswa, yang nantinya harapannya adalah siswa mampu untuk bekerja. Hal tersebut dijelaskan oleh subjek SMR dalam W/SMR/22-03-2014 bahwa "...berusaha agar anak-anak itu e lebih mandiri lagi disektor apapun ya..disektor apapun itu anak-anak bisa apa, bisa bekerja itu. anak-anak juga sudah kita bekali berbagai keterampilan..nah itu e mudah-mudahan juga bisa dijadikan bekal."

\section{Responden BP}

Bentuk sikap dari kompetensi pedagogik yang dilakukan oleh subjek BP guru harus mengikuti berbagai aturan profesi yang dibuat oleh pemerintah. Meskipun begitu, tugas terberat guru adalah bagaimana membekali dan memajukan anak untuk menjadi lebih baik. Hal ini ditegaskan oleh subjek BP dalam W/BP/15-04-2014 "guru yang profesional itu adalah guru yang bisa memajukan anaknya, itu intinya". Hal yang paling berat bagi guru adalah bagaimana membekali anak untuk menjadi lebih baik. Selain itu, guru juga harus mengikuti berbagai aturan yang ditetapkan oleh pemerintah.

\section{Responden BSN}

Seorang guru pendidikan khusus harus membuat perencanaan pembelajaran. Seperti yang dijeaskan oleh subjek BSN dalam W/BSN/28-04-2014 bahwa “...untuk dikatakan kita profesional ataupun ada tugas yang berkaitan kitan ngajar entah membuat rpp. Bentuk tanggung jawab itu yang seperti itu, jadi tugas kewajiban guru sebagai pembantu perencanaan juga dilakukan, tugas-tugas dari sekolah pun harus kita lakukan seperti itu."Dari hasil penelitian di atas dan untuk menjawab tujuan dari penelitian maka dapat dijabarkan pembahasan sebagai berikut:

Kompetensi Kepribadian

\section{Responden HT}

Guru pendidikan khusus yang profesional harus memiliki kepribadian yang baik. Kepribadian tersebut diantaranya dapat bertindak dan berperilaku sebagai panutan. Hal tersebut dijelaskan oleh subjek HT dalam W/HT/06-01-2014 yaitu "seorang guru harus bisa mempersiapkan diri dalam bertindak, bertingkah laku yang baik sebagai panutan"

Selain itu untuk mencerminkan pribadi yang bai, seorang guru pendidikan khusus juga harus memiliki disiplin yang tinggi. Disiplin ini dapat berupa memiliki jadwal perencanaan kegiatan, mampu membagi waktu antara kegiatan di rumah dan di sekolah. Hal ini dipertegas dengan pernyataan dari subjek HT pada W/HT/06-01-2014 “Guru yang profesional itu kan harus mempunyai jadwal yang e...yang baku istilahnya. ...kita sudah mempunyai rencana yang..yang baku, mempunyai rencana yang matang dan mempuyai rencana yang sudah menjadi rutinitas kita yang kita kerjakan antara pengelolaan waktu dinas dan diluar dinas seperti itu."

Kepribadian seorang guru pendidikan khusus lainnya dapat dibuktikan dengan memiliki rasa tanggungjawab, tanggung jawab tersebut dapat berupa tanggung jawab terhadap pekerjaan maupun tanggungjawab terhadap siswa. Seperti penjelasan dari subjek HT pada W/HT/0601-2014, yaitu "Kalau pas dinas ya..full kita harus berada disekolahan karena itu tanggungjawab kita misalnya kalau dijogja itu harus 37,5 jam. Antara jam 7 sampai dengan jam 2 ya..kita usahakan dan apa? Kita berusaha semaksimal mungkin untuk jam-jam itu tidak pernah meninggalkan sekolah."

Dalam melakukan pekerjaannya, seorang guru pendidikan khusus juga mengedepankan rasa ikhlas dan sabar. Seperti 
yang dijelaskan dalam wawancara dengan subjek HT bahwa kesabaran dan keikhlasan adalah sebuah tantangan tesendiri bagi guru pendidikan khusus yaitu pada W/HT/06-01-2014 "Tantangannya ikhlas, sabar."

Selain keikhlasan dan kesabaran yang harus dimiliki oleh seorang guru pendidikan khusus lainnya yaitu adanya pengabdian yang tulus untuk menjadi guru pendidikan khusus. Seperti yan ditegaskan oleh subjek HT dalam wawancara W/HT/06-01-2014, yaitu "Prinsipnya kalau untuk anak-anak sekolah luar biasa adalah pengabdian yang tulus. Kemudian apa namanya, melaksanakan sesuai dengan profesionalisme guru.

\section{Responden SMR}

Dalam kompetensi profesional yang dilakukan oleh subjek SMR juga tidak jauh berbeda dengan subjek HT. Subjek SMR melakukannya dengan kemampuan untuk membagi waktu antara pekerjaan di sekolah dengan pekerjaan di rumah. Seperti dijelaskan dalam wawancara W/SMR/2203-2014 bahwa "Ya kalau mengelola diri ya biasa sama dengan yang lain ya..bagi waktulah antara pekerjaan sekolah, pekerjaan rumah tangga, pekerjaan entah di masyarakat."

Kepribadian lainya yang ditunjukkan untuk menjadi seorang guru pendidikan khusus yaitu dalam bekerja dilandasi karena ibadah sehingga pekerjaan dapat dikerjakan dengan ikhlas. Hal tersebut dijelaskan oleh subjek SMR dalam wawancara pada W/SMR/22-03-2014 bahwa "Jadi saya kerja mesti saya landasi ibadah agar pekerjaan saya itu tetep diatas aturan sehingga apa yang saya lakukan bener-bener ikhlas itu dan kemudian juga bernilai pahala dan buat saya itu."

Pengembangan profesionalisme yang lain dari subjek SMR juga hampir sama dengan subjek HT bahwa mampu memandirikan siswa. Ha ini ditegaskan oleh subjek SMR pada W/SMR/22-03-2014 bahwa “...yang jelas kan kita harus bisa memandirikan anak ya sebetulnya itu apa kalau itu dikatakan prinsip ya pokoknya anak itu apa..harus bisa mandiri."

Selain itu sebagai pribadi yang baik, guru pendidikan khusus tentu saja harus memberikan perhatian dan kasih sayang kepada anak berkebutuhan khusus apapun kondisi dan keadaan kita. Hal tersebut ditegaskan oleh hasil wawancara dengan subjek W/SMR/22-03-2014 bahwa "dan saya tetap menganggap bahwa itu adalah titipan dari Allah buat saya, dan kita jga memberikan perhatian kepada mereka apapun kondisi dan keadaan kita.

Kepribadian yang baik lainnya dari seorang guru pendidikan khusus yaitu mampu memberikan motivasi dan contoh yang baik pada teman atau guru lainnya. Ini ditegaskan dalam pernyataan yang sampaikan oleh subjek SMR pada W/SMR/22-03-2014 yaitu "mengikuti lomba-lomba itu kan paling tidak memotivasi diri sendiri maupun memotivasi temanteman ya? Juara ataupun enggak itu kan bukan masalah. Bagaimana kita memotivasi diri belajar apa yang kita lihat itu kita tulis. Pengembangan itu kan ya memberikan contoh kepada teman-teman bagaimana kemarin saya memperoleh beberapa kejuaraan, dan itu kan dalam rangka kita memotivasi."

\section{Responden BP}

Secara kepribadian subjek BP lebih menekankan pada kedisiplinan yang merupakan bentuk dari tanggungjawab terhadap regulasi dari pemerintah. Hal ini dijelaskan dalam W/BP/15-04-2014 bahwa "Kan pemerintah itu membuat regulasi, saya berkedudukan saya sebagai PNS, saya mengikuti regulasi yang di atur oleh pemerintah. Apapun ya? Regulasi kan macemmacem, ya di bidang kedisiplinan, di bidang administrasi atau dibidang manajemen pendidikan itu, itu yang saya lakukan.

\section{Responden BSN}

Untuk menjadi seorang guru SLB yang profesional membutuhkan proses yang panjang, tidak serta merta begitu saja. Ada banyak tantangan dan permasalahan yang akan ditemui untuk mencapai profe- 
sionalisme kerja, maka dari itu, seorang guru SLB yang profesional diharapkan dapat memiliki kepribadian yang kuat. Hal ini ditegaskan oleh subjek BSN dalam W/BSN/28-04-2014 "seorang guru pribadi guru LB itu sabar menghadapi yang bermasalah yang terhambat itu tadi sehingga ini akan menjadikan betul-betul mental guru SLB itu e... dicoba di lapangan dalam waktu cukup..."

Berbeda lagi dengan yang diungkapkan oleh subjek IV Bapak BSN pada $\mathrm{W} / \mathrm{BSN} / 28-04-2014$ yang mengatakan bahwa "...kita bekerja itu adalah ibadah, yang penting niat kita ikhlas. itulah nilainilai yang harus kita junjung tinggi sebagai guru SLB."

Apalagi anak didik kita adalah mereka yang berkebutuhan khusus. Menurut subjek BSN dalam W/BSN/28-04-2014 “...beberapa sikap yang harus dimiliki oleh seorang guru SLB adalah "bertanggung jawab, selalu berpositive thinking, dan menjaga kepercayaan."

Kompetensi Sosial

Responden HT

Kompetensi sosial yang ditunjukkan dari seorang guru pendidikan khusus tidak adanya diskriminasi terhadap siswa, menganggap bahwa semua siswa itu sama termasuk bagi anak berkebutuhan khusus. Seperti yang dilakukan oleh subjek HT yang dijelaskan pada wawancara W/HT/06-01-2014 “...yang diberikan, label yang diberikan orang lain mengapa mengajar anak luar biasa gitu? Ya..itu kan tantangan. Jadi kita harus menunjukkan bahwa manusia itu semua sama. Di undangundang juga di sebutkan kalau semua warga negara berhak mengenyam pendidikan, memperoleh pendidikan."

\section{Responden SMR}

Bentuk kompetensi sosial yang dilakukan oleh subjek SMR yaitu dengan tidak melakukan diskriminasi terhadap siswa berkebuthan khusus. Hal tersebut dia jelaskan dalam hasil wawancara pada W/SMR/22-03-2014 yang menyatakan bahwa "memotivasi diri sendiri maupun memotivasi teman-teman ya? Juara ataupun enggak itu kan bukan masalah. Bagaimana kita memotivasi diri belajar apa yang kita lihat itu kita tulis. Pengembangan itu kan ya memberikan contoh kepada temanteman.

\section{Responden BP}

Kompetensi sosial dari subjek BP diwujudkan dalam mengikuti secara aktif kegiatan di lingkungan masyarakat. Kegiatan tersebut seperti menjadi ketua RT, menjadi penasihat kampung, menjadi panitia dalam kegiatan hajatan yang ada di lingkungan tempat tinggal. Hal ini ditegaskan oleh informan W/IF2/SKR/1610-2014 bahwa "Kalau di masyarakat khususnya di kompleks saya memang beliau pernah terangkat menjadi ketua RT, disamping itu sekarang ini menjadi istilahnya konsultan apa ya? Penasihat dalam segala kegiatan di kompleks kami karena memang dirasa beliau mungkin di pandang lebih daripada yang lain.

\section{Responden BSN}

Guru SLB merupakan profesi yang mulia. Hal tersebut terlebih dahulu harus ditanamkan dalam diri setiap guru SLB. Mulia tidaknya seorang guru SLB harus diakui oleh lingkungan. Seperti yang ditegaskan oleh subjek BSN dalam W/BSN/28-04-2014 “....kita juga akan menjadi seorang profesional apabila di dalam SLB itu menerima kondisi kita sehingga dalam e...tindak lanjutnya dengan keikhlasan kita, dengan apada adanya kondisi di lapangan itu dengan anakanak seperti itu jadi sesuai kondisi kita harus siap menerima apa adanya."

Oleh karena itu, guru harus pintarpintar beradaptasi, berinteraksi, dan membangun hubungan yang baik dengan lingkungan kerjanya, dengan teman-teman kerjanya. Salah satu manfaat membangun pertemanan dalam dunia kerja menurut subjek BSN dalam W/BSN/28-04-2014 yaitu "walaupun kita profesional tapi kita kan masih ada sesuatu yang belum bisa 
kita tangani, nah itu perlu mungkin pengalaman teman akan bisa kita aplikasikan."

Membangun pertemanan di dunia kerja juga menjadi hal yang sangat penting karena seringkali guru mendapat beberapa tugas secara bersamaan atau ditekan oleh beberapa kepentingan sekaligus. Hal ini diperjelas oleh pernyataan subjek BSN dalam W/BSN/28-04-2014 "nah untuk mengatasi seperti ini kan kita harus betulbetul ada kerja sama dengan teman yang baik, minimal itu, sehingga kita itu punya teman yang bisa menghandle, tapi kita suatu saat juga harus bisa, jadi kita harus bisa sosialitas dengan teman gitu"

Kompetensi Profesional

Responden HT

Dalam kompetensi profesional guru pendidikan khusus sangat berkaitan erat dengan bentuk pengembangan profesionalisme yang dilakukan oleh guru. Sikap profesionalisme guru dapat ditunjukkan dengan memiliki kreativitas dan inovasi. Hal ini dijelaskan oleh subjek HT dalam W/HT/06-01-2014 "Inovasi itu harus. Kalau guru tidak kreatif, tidak punya kreatifitas, tidak punya inovasi kan nantinya jga siswa yang seharusnya bisa di kembangkan dalam hal lain, maksudnya dia sudah non-akademik dikembangkan misalnya kemampuan yang lain keterampilan atau bakat atau...apa saja kalau kita tidak inovasi, kita tidak kreatif kan kita tidak bisa tahu anak itu sebenarnya mempunyai kemampuan yang tersimpan."

Bentuk dari kompetensi profesional lainnya yaitu melakukan pengembangan dalam bidang pembelajaran seperti media, metode, dan lainnya. Subjek HT juga menjelaskan dalam hal ini pada W/HT/0601-2014 yaitu "kita berkreasi kita menemukan hal-hal dan mencoba dan mencoba halhal yang tepat untuk pembelajaran, baik multi media, metode, mungkin juga yang lainnya."

Pengembangan profesionalisme dari guru pendidikan khusus dapat dilakukan dengan mandiri maupun dapat dilakukan oleh instasi penyelenggara. Pengembangan secara mandiri dapat dilakukan dengan mengakses informasi dari berbagai media, membaca. Untuk pengembangan yang dilakukan oleh instansi penyelanggara dapat dilakukan dengan seminar, workshop. Hal tersebut dijelaskan oleh subjek HT dalam W/HT/06-01-2014 “...pengembangan diri itu memang harus kita mengakses segala informasi untuk itu, baik dari media elektronik, dari mengikuti seminar, mengikuti workshop, membaca."

\section{Responden SMR}

Dalam melakukan pengembangan profesionalisme guru pendidikan khusus yang dilakuka oleh subjek SMR juga tidak jauh berbeda dengan subjek HT. Pengembangan dilakukan secara mandiri maupun dilakukan oleh pemerintah. Pengembangan secara mandiri dilakukan oleh subjek SMR dengan cara belajar terus menerus, membaca buku, mengikuti lomba-lomba. Sedangkan pengembangan yang dilakukan oleh instansi yaitu dapat dilakukan dengan workshop dan diklat. Hal ini dijabarkan dalam kalimat bahwa "Ya kalau mengelola kinerja e...saya..apa..selama ini ya terus belajar ya...terus belajar itu bisa membaca buku, kemudian bisa diskusi dengan teman-teman atau sekolah. Ya kalau bentuk pengembangannya mengikuti workshop, diklat, lomba-lomba gitu."

\section{Responden BP}

Pendapat subjek "untuk menghadapi atau mengajar anak-anak berkebutuhan khusus itu tetap perlu belajar terus". Hal ini dikarenakan setiap anak berkebutuhan khusus memiliki karakteristik masing-masing yang bersifat unik sehingga meskipun memiliki keterbatasan yang sama, misal sama-sama anak tunagrahita, tetapi penanganannya dapat berbeda disesuaikan dengan perbedaan individual yang ada. Dalam hal ini, belajar tidak hanya melalui teori-teori mengenai anak berkebutuhan khusus, tetapi juga belajar dari anak itu sendiri karena ada banyak hal baru yang dapat ditemui langsung pada anak dan mungkin belum ada di teori. Dengan modal terus belajar, guru diharapkan dapat 
memajukan anak sesuai dengan kemampuan dan potensinya.

Pengelolaan waktu menjadi sebuah hal yang sangat penting dalam menunjang profesionalisme kerja seorang guru. Salah satu hal terkait dengan pengelolaan waktu yang sering menjadi permasalahan adalah seringnya pekerjaan sekolah dibawa pulang sampai ke rumah. Hal ini seringkali memicu sebuah permasalahan dengan pasangan karena idealnya pekerjaan sekolah itu dikerjakan di sekolah, sedangkan di rumah adalah waktunya bersama keluarga. Hal tersebut dialami oleh subjek BP seperti yang tercantum dalam hasil wawancara W/BP/15-04-2014 berikut ini "saya tidak bisa mencurahkan pekerjaan hanya pada waktu jam kerja, tetapi sampai di rumah. Nah ini efeknya sampai di rumah itu menjadi sering adanya ketidakcocokan dengan pasangan..."

Seseorang dalam melakukan sebuah pekerjaan haruslah sesuai dengan aturan yang ada. Seperti yang diungkapkan oleh Subjek III pada W/BP/15-04-2014 "...kan pemerintah itu membuat regulasi, saya berkedudukan saya sebagai PNS, saya mengikuti regulasi yang di atur oleh pemerintah. Apapun ya? Regulasi kan macemmacem, ya di bidang kedisiplinan, di bidang administrasi atau dibidang manajemen pendidikan itu, itu yang saya lakukan."

Pendapat lainnya lagi juga berbeda dari subjek III Bapak BP pada W/BP/15/04/2014 mengungkapkan “Saya kira orang bekerja itu kan kepuasannya itu pada keberhasilan anak. Kalau anak itu yang dari awalnya tidak bisa kemudian menjadi bisa, itulah keberhasilan. Dan itu adalah merupakan kepuasan bagi saya dan itu menjadi sebuah kebanggaan, saya kira itu dan saya tidak bisa menjawab yang lain."

Sertifikasi bukanlah tolak ukur yang tepat untuk mengukur profesionalisme guru. Hal ini dikarenakan masih banyak guru yang sudah mendapatkan sertifikasi tetapi masih belum menunjukkan profesionalisme kerja, seperti datang selalu terlambat setiap hari. Menurut subjek BP dalam $\mathrm{W} / \mathrm{BP} / 15-04-2014$ "Mungkin cara meng- ukur guru yang profesional itu yang perlu diperbaiki tolak ukurnya, karena mungkin selama ini kan ya sama saja, mengikuti tes lulus, diklat lulus, kan sudah. Nah tetapi kenyataan di lapangan nanti kan berbeda."

Ada banyak cara pengembangan diri yang dapat dilakukan oleh seorang guru profesional. Beberapa bentuk pengembangan diri yang dilakukan oleh subjek BP dalam W/BP/15-04-2015 yaitu "saya menempuh pendidikan formal pendidikan lanjut, saya juga mengikuti diklat-diklat yang diselenggarakan oleh pemerintah.... dan yang lebih pokok itu pengembangan diri itu melalui organisasi-organisasi yang ada". Beberapa organisasi yang berkaitan dengan guru diantaranya PGRI, KKG, MGMP, dan sebagainya.

\section{Responden BSN}

Untuk menjadi seorang guru yang profesional, guru tidak boleh berhenti belajar untuk mengembangkan diri dan kompetensinya. Belajar dilakukan untuk menambah pengetahuan dan wawasan mengenai anak berkebutuhan khusus. Salah satu cara belajar yang dapat dilakukan adalah dengan membaca. Menurut subjek BSN dalam W/BSN/28-04-2014 “...kalau saya sering ke toko buku itu cari buku-buku yang berkaitan dengan ABK. Baik itu ABK yang sudah e.. kita tangani atau yang belum..kalau yang sudah kita tangani berrati kita memperdalam lagi, kalau yang belum berarti kita belajar tidak apa-apa to sehingga disini kita akan menambah personality kita."

Selain itu, cara lain yang dapat dilakukan dalam upaya pengembangan diri menurut subjek BSN dalam W/BSN/28-042014 adalah "kita juga harus minimal aktif dalam kegiatan-kegiatan yang berupa pengembangan guru itu, baik dalam bentuk workshop".

Profesionalisme kerja harus didukung oleh manajemen kerja yang baik. Profesional tidak hanya dinilai dari kinerjanya di tempat kerja tetapi juga diukur dari kemampuan seseorang dalam menyeimbangkan kehidupan pribadi dengan kehidupan profesionalnya. Hal ini ditegaskan 
oleh subjek BSN dalam W/BSN/28-042014 "janganlah katakan profesional jika dia sukses di sekolah tapi keluarganya bubrah itu tidak, itu belum profesional."

Manajemen kerja juga harus ditunjang oleh manajemen waktu yang baik. Untuk menghindari adanya ketidakseimbangan antara kehidupan keluarga dan kehidupan profesional kerja, ada beberapa strategi manajemen waktu yang dapat dilakukan oleh guru menurut subjek BSN dalam W/BSN/28-04-2014 “...pas jam kosong kita gunakan untuk mengerjakan tugas-tugas, itu yang disebut profesional, tidak pas kosong kita ngerumpi tidak..." atau "....ya kita usahakan bangun agak malam, bangun agak malam ya sekitar jam tiga lah, jam tiga, setengah empat kita bangun untuk menyelesaikan pekerjaan itu."

Menurut subjek BSN dalam W/BSN/28-04-2014, seorang guru yang sudah mendapatkan sertifikasi belum tentu profesional. Alasannya masih banyak yang bermain hp selama mengajar, ngerumpi, media pembelajaran pinjam teman, dan tidak memiliki buku harian atau buku kemajuan kelas.

\section{Bentuk Pengembangan Profesionalisme} Guru

Bentuk pengembangan profesionalisme guru yang dilakukan oleh masingmasing subjek berbeda. Subjek memiliki cara-cara tersendiri seperti subjek HT melakukan pengembangan profesionalismenya dengan cara membaca, melakukan inovasi dalam bidang pembelajaran baik itu media maupun metode. Subjek SMR melakukan pengembangan profesionalisme dengan cara belajar terus menerus, membaca, mengikuti lomba, mengikuti workshop, mengikuti diklat. Bentuk pengembangan profesionalisme yang dilakukan oleh subjek BP yaitu belajar terus menerus, mengikuti diklat dan seminar yang diselenggarakan sekolah maupun pemerintah, mengikuti organisasi pendidikan. Sedangkan bentuk pengembangan profesionalisme guru yang dilakukan oleh subjek BSN yaitu belajar terus menerus, membaca, aktif dalam kegiatan pengembangan guru seperti workshop dan diklat.

\section{Simpulan dan Saran}

\section{Simpulan}

Hasil penelitian profesionalisme guru pendidikan khusus berkaitan dengan: profesionalisme guru pendidikan khusus yaitu berdasarkan sebagai berikut. Pertama, kompetensi pedagogik keempat subjek membuat perencanaan pembelajaran. Selain itu, subjek SMR memahami kondisi siswa dan memandirikan siswa dalam perencanaan pembelajaran, serta subjek BP memandirikan siswa. Kedua, kompetensi kepribadian dilakukan keempat subjek dengan cara menjadi panutan, disiplin, bekerja dengan ikhlas. Sedangkan dari tiga subjek selain subjek BP melakukan pengabdian yang tulus, tanggungjawab terhadap pekerjaan, berpikir positif, dan menjaga kepercayaan. Ketiga, kompetensi sosial diwujudkan dengan sikap tidak adanya diskriminatif dari subjek HT dan subjek SMR. Sedangkan yang dilakukan subjek BP dan subjek BSN yaitu berperan aktif dalam kegitan di masyarakat.

Keempat, kompetensi profesional dilakukan keempat subjek dengan belajar terus menerus, mengikuti workshop dan diklat, serta menulis buku dalam bidang pengembangan pembelajaran. Hal lain yang dilakukan subjek SMR dengan mengikuti lomba, sedangkan subjek BP dengan menempuh jenjang pendidikan yang lebih tinggi serta mengikuti kegiatan organisasi kependidikan. Bentuk pengembangan profesionalisme guru terdapat dalam kompetensi profesional. Sehingga bentuk pengembangan yang dilakukan dari empat subjek yaitu belajar terus menerus, mengikuti workshop dan diklat, serta menulis buku pembelajaran. Subjek SMR menambahkan dengan mengikuti kegiatan lomba. Sedangkan subjek BP juga melakukan pengembangan lainnya dengan cara menempuh pendidikan formal pada jenjang yang lebih tinggi serta aktif mengikuti organisasi yang berkaitan dengan bidang pendidikan. 
Saran

Berdasarkan hasil penelitian di lapangan, ada beberapa saran yang penulis berikan terkait profesionalisme guru pendidikan khusus yaitu: Bagi guru pada umumnya dan guru pemula pada khususnya untuk menjadi seorang guru pendidikan khusus harus mampu mengembangkan profesionalisme guru dengan cara membaca, menulis, menempuh pendidikan formal pada jenjang yang lebih tinggi, mengikuti pendidikan dan pelatihan (diklat), workshop, seminar, mengikuti organisasi yang berkaitan dengan pendidikan.

\section{Daftar Pustaka}

Borang, D.S. (2009). Upaya Peningkatan Kompetensi dan Profesionalisme Guru SMK di Era sertifikasi dalam Seminar internasional Peran LPTK dalam Pengembangan pendidikan Vokasi di Indonesia, Unima.

Case, et al. (2009). Guru profesional. (Terjemahan Suci Ramadhona). California. Jossey-Bass Inc Publisher. (Bu$\mathrm{ku}$ asli terbitan tahun 1999).

Danim, S. (2011). Pengembangan profesi guru dari pra-jabatan, induksi, ke profesional madani. Jakarta: Kencana Prenada Media Group

Djamarah. (2010). Guru dan anak didik dalam pendekatan edukatif. Jakarta: Rineka Cipta.

Eunjung Choi. (2010). A case study of an early childhood inclusive program: teacher professional development and collaboration. UMI Dissertation Publishing, 3436054.
Hardianto, D. (209). Pendidikan guru dan upaya meningkatkan profesionalisme guru. Disampaikan pada Seminar nasional IPTPI tanggal 18 November 2009.

Hamalik, O. (2002). Pendidikan guru berdasarkan pendekatan kompetensi. Jakarta: PT. Bumi Aksara.

Hyeyoung Hwang. (2010). The influence of ecological contexts of teacher education on south Korean teacher educator' professional development. UMI Dissertation Publishing, 3448862.

Hinds, M. J. (2007). A case study: teacher professional development and its impact on the improvement of practice in one Ontario secondary school. Ottawa. Canada University.

Milles \& Huberman. (1994). Qualitative data analysis. New Delhi: SAGE Publication.

Mudlofir.(2012). Pendidik professional. Jakarta: Raja Grafindo Persada.

Presiden. (2008). Peraturan Menteri Pendidikan Nasional Republik Indonesia Nomor 32 Tahun 2008 tentang Standar Kualifikasi Akademik Guru Pendidikan Khusus.

Presiden. (2008). Peraturan Pemerintah Nomor 74 Tahun 2008 Tentang Guru.

Republik Indonesia. (2005). Undang-Undang Nomor 14 Tahun 2005 Tentang Guru dan Dosen.

Nasution, S. (1988). Metodologi penelitian naturalistik kualitatif. Bandung: Tarsito. 